Article

\title{
Effects of Farming Activities on the Temporal and Spatial Changes of Hydrogen and Oxygen Isotopes Present in Groundwater in the Hani Rice Terraces, Southwest China
}

\author{
Chengjing Liu $\oplus^{\oplus}$, Yuanmei Jiao *, Dongmei Zhao, Yinping Ding, Zhilin Liu and Qiue Xu \\ School of Tourism and Geographical Sciences, Yunnan Normal University, No. 768 Juxian Street, Chenggong \\ District, Kunming 650500, China; 18487101130@163.com (C.L.); 18487365270@163.com (D.Z.); \\ dyp520513@163.com (Y.D.); zhilin2015@foxmail.com (Z.L.); 15974668403@163.com (Q.X.) \\ * Correspondence: ymjiao@sina.com; Tel.: +86-1388-808-3272
}

Received: 16 December 2019; Accepted: 14 January 2020; Published: 17 January 2020

check for updates

\begin{abstract}
Landform changes caused by human activities can directly affect the recharge of groundwater, and are reflected in the temporal and spatial changes in groundwater stable isotope composition. These changes are particularly evident in high-intensity farming areas. In this study, we tested and analyzed groundwater stable isotope samples at different elevations of rice terraces in a typical agricultural watershed of the Hani Terraces, a World Heritage Cultural Landscape in southwest China. Thus, we determined the characteristic variations and factors that influence the temporal and spatial effects on groundwater stable isotopes in the Hani Terraces, which are under the influence of high-intensity farming activities. The elevation gradients of $\delta^{18} \mathrm{O}$ and $\delta^{2} \mathrm{H}$ in groundwater are significantly increased due to farming activities. The values were $0.88 \%$ o $(100 \mathrm{~m})^{-1}$ and $-4.5 \% \mathrm{o}(100 \mathrm{~m})^{-1}$, respectively, and they changed with time. The groundwater circulation cycle is approximately three months. We also used the special temporal and spatial variation characteristics of the groundwater isotopes as a way to evaluate the source and periodic changes of groundwater recharge. In addition, high-intensity rice farming activities, such as ploughing every year from October to January can increase the supply of terraced water to groundwater, thus ensuring the sustainability of rice cultivation in the terraces during the dry season. This demonstrates the role of human wisdom in the sustainable and benign transformation of surface cover and the regulation of groundwater circulation.
\end{abstract}

Keywords: Hani Rice Terraces; hydrogen and oxygen isotopes; groundwater recharge; elevation effect; deuterium excess

\section{Introduction}

Groundwater, as the world's largest freshwater resource, is critically important for irrigated agriculture, and hence for global food security [1]. The increasing use of groundwater resources for human consumption, agriculture, and industrial uses requires the protection of recharge areas from contamination or land use and land cover changes that may affect the quality and quantity of water in the aquifers [2-4]. Furthermore, climate change has the potential to exacerbate the problem in some regions. For example, it is predicted that anthropogenic climate change will affect rainfall amount and distribution in many parts of the world [5-8]. Under the influence of both climate change and human activities, depletion of water is widespread in large groundwater systems in both semi-arid and humid regions of the world [1]. Consequently, documenting the spatial patterns and determining 
the magnitude of groundwater recharge is important for understanding and managing groundwater systems using the appropriate tools [4].

One of the major changes that has occurred in earth and environmental sciences is the addition of rigorous analytical tools such as isotopes, to complement classical descriptive methods [9]. For example, the isotopic ratios of chemical elements such as oxygen and hydrogen of the water molecule $\left({ }^{18} \mathrm{O} /{ }^{16} \mathrm{O}\right.$ and ${ }^{2} \mathrm{H} /{ }^{1} \mathrm{H}$, respectively) are used as powerful tools to trace isotopes in hydrological processes [10-13]. Without any evaporation and exchange with dissolved gases or rocks, the stable isotopes $\left({ }^{18} \mathrm{O}\right.$ and $\left.{ }^{2} \mathrm{H}\right)$ can be considered as conservative, and thus reflect the mixture of the different recharge at the origin of the groundwater. Meanwhile, the abundance of ${ }^{18} \mathrm{O}$ and ${ }^{2} \mathrm{H}$ is driven by environmental conditions such as recharge altitude, recharge water source, and ambient temperature, which leads to a specific signature in the groundwater [14-16].

Since the 1970s, hydrogeologists have used stable water isotopes $\left({ }^{2} \mathrm{H}\right.$ and $\left.{ }^{18} \mathrm{O}\right)$ as tracers to explain the isotopic characteristics of groundwater across the seasons, and calculate groundwater recharge sources and the groundwater recharge altitude [17-19]. As research continued, groundwater recharge, the relationship between groundwater and surface water, the origin and evolution of groundwater, and groundwater quality gained increasing attention [20-23]. These studies have made a positive contribution towards understanding groundwater processes, protecting regional water resources, achieving regional water cycle stability, and maintaining the sustainability of social production and life.

Groundwater recharge in both moist and arid areas is susceptible to changes in land use/land cover, especially when this is due to human activities [24-26]. Previous studies have suggested that the global impact of land use and cover change (LUCC) on the hydrologic cycle may surpass that of recent climate change $[27,28]$. In Australia, removal of indigenous vegetation over the past 100 years has significantly increased groundwater recharge and caused a rise in the water-table [29]. Research on the Loess Plateau showed that groundwater recharge beneath natural sparse small-grass was $100 \mathrm{~mm} /$ year, but the conversion to winter wheat about 100 years ago reduced the groundwater recharge to $55 \mathrm{~mm} /$ year [26]. Therefore, the traditional recharge estimation method and isotope effect of groundwater has large errors in some areas.

This situation is particularly prominent in agricultural areas where humans have exerted large-scale changes on the terrestrial biosphere, primarily through agriculture. For example, Liu et al. (2016) studied the groundwater in the Malizhai River basin of the Hani Terraces and found that groundwater in the terrace area had different elevation gradients at different elevations [30]. Further analysis by Jiao et al. (2017) showed that the dominant landscape types at different elevations have a significant impact on the isotope composition of underground spring water [31]. This impact is mainly manifest in differences in the elevation gradients of stable isotopes present in spring water within the same landscape type and between different landscape types. All of the unique variations in the elevation effect on groundwater isotopes in this area point to the influence of changes in regional land use. At present, it is known that land use change can affect the infiltration of surface water. However, it is necessary to further analyze how land use change influences groundwater isotopes and their temporal and spatial distribution, especially the impact of the land use change caused by agricultural activities on regional groundwater circulation.

In this paper, we (1) analyzed the features of the elevation effect on the oxygen and hydrogen isotopic composition of groundwater across month and year; (2) analyzed and identified the influencing mechanisms of land use change caused by farming activities on the elevation gradient of groundwater isotopes from a spatial perspective; (3) estimated the recharge cycle and period of regional groundwater from a temporal perspective using the deuterium excess; and (4) deepened our understanding of how farming activities can improve groundwater recharge efficiency and maintain agricultural sustainability.

\section{Study Area}

The study area is located in the Bada area, the core area of the Hani Terraces, a World Heritage Cultural Landscape in Yuanyang County, Yunnan Province. It belongs to the Quanfuzhuang catchment 
of the upstream tributary of the Malizhai River basin, located on the northern slope of the Southern Ailao Mountains, with the longitude ranging from $102^{\circ} 43^{\prime} 16^{\prime \prime}$ to $102^{\circ} 50^{\prime} 39^{\prime \prime} \mathrm{E}$, and the latitude ranging from $23^{\circ} 5^{\prime} 20^{\prime \prime}$ to $23^{\circ} 13^{\prime} 18^{\prime \prime} \mathrm{N}$ (Figure 1). The terrain in the whole catchment is high in the north and low in the south. The catchment is fan-shaped from north to south, covering an area of $13.92 \mathrm{~km}^{2}$. It accounts for $16.73 \%$ of the total area of the Malizhai River basin $\left(83.2 \mathrm{~km}^{2}\right)$. The elevation of the catchment ranges from $1475 \mathrm{~m}$ to $2261 \mathrm{~m}$. The elevation of the terrace area within the catchment ranges from $1475 \mathrm{~m}$ to $1737 \mathrm{~m}$. The terrace area is located in the middle and lower reaches of the catchment and accounts for approximately $40 \%$ of the total area of the catchment. The terrain is characterized by a change from gentle slopes to steep slopes, with steepness mainly $>25^{\circ}$. In terms of the climate, the annual precipitation is $1532.19 \mathrm{~mm}$, and the annual evaporation is $1500.60 \mathrm{~mm}$. The distribution of precipitation in the dry and rainy seasons is uneven. The rainy season is generally considered to be from May to October, and the dry season is from November to April. The precipitation in the rainy season accounts for $72 \%$ and the dry season precipitation accounts for $28 \%$. The entire catchment belongs to the headwater area of the Malizhai River, a first-order tributary on the right bank of the Yuanjiang River in the upper reaches of the Honghe River. Abundant rainfall in the catchment provides sufficient water for the river. The drainage system of the catchment develops in the form of tree branches. There are two primary tributaries in the east and the west, which merge into the Malizhai River at the lowest part of the catchment. In addition, due to the impact of the fault structures and deep cutting terrain, the bedrock fissure water in the area mostly migrates from high to low water levels. It is discharged in the form of springs or diffused flow in gullies and foothills, according to the characteristics of recharge and discharge in the vicinity. In the study area, a large amount of groundwater is discharged into springs.
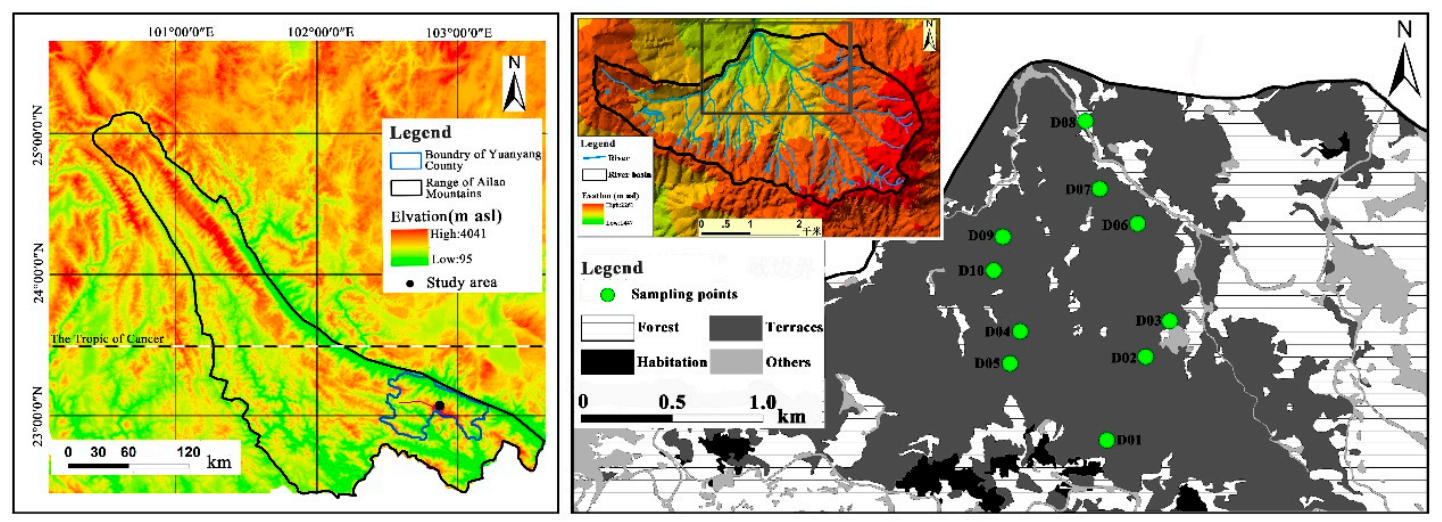

Figure 1. Study area and distribution of sampling points.

According to field investigation and the 1:200,000 regional geological report of the Yuanyang area [32], there are two types of aquifer: pore aquifer and fissured aquifer, in which the pore aquifer includes Qualified Design Listing (Qdl) and Qualified Eluvium Listing (Qel). The thickness of two strata with weak water abundance is between $0.1 \mathrm{~m}$ and $10 \mathrm{~m}$. The fissured aquifer is gneiss and granulite in the lower part of the formation, with developed cracks and joint. There is a network of cracks in the weathering zone of these rocks. The difference in water abundance is controlled by the degree of development of cracks and joints. As a whole, the water abundance is better. Moreover, the water permeability of the rock with undeveloped joints and cracks is poor, forming an aquiclude. Precipitation is the most important source of groundwater recharge. The runoff discharge and buried depth of groundwater are obviously controlled by the terrain. Generally, groundwater has a short recharge path, with on-site recharge and on-site discharge. However, the groundwater is also recharged with the surface water in the terrace area and the lateral infiltration water of the upper terrace and the lower terrace, but the overall recharge is weak. In terms of the hydrochemical characteristics of the water in the River basin, the groundwater in the rainy season is classified as $\mathrm{HCO}_{3}-\mathrm{Ca}$ with a $\mathrm{pH}$ value of 7.76 and total hardness of 81.54 . The groundwater in the dry season is $\mathrm{HCO}_{3}-\mathrm{Ca} \cdot \mathrm{Na}$ with 
a $\mathrm{pH}$ value of 6.89 and total hardness of 7.46 . The ion content of the groundwater varies greatly in the dry and rainy seasons, which indicates that the recharge sources of groundwater are different in different seasons.

\section{Data Sources and Research Methods}

\subsection{Sample Collection and Testing}

Remote sensing image interpretation and digital elevation model analysis were conducted in the study area. Based on the results of our field investigation and taking into account water isotope sampling standards and precautions, sampling points were arranged along different elevation gradients in the Quanfuzhuang catchment of the Hani Terraces. The elevation of the sampling points ranged from $1500 \mathrm{~m}$ to $2260 \mathrm{~m}$, and the difference in elevation was $760 \mathrm{~m}$ (Figure 1). Samples were collected for one year from May 2015 to April 2016, and the time of alternation between dry and rainy seasons was kept consistent in order to comprehensively observe the change in isotope composition of samples in a dry-rainy season cycle. Ten groundwater sampling points were established and 120 groundwater samples were obtained. All the groundwater samples are spring water with a slow flow rate $(0 \sim 0.2 \mathrm{~m} / \mathrm{s})$.

The hydrogen and oxygen isotope tests were conducted in the Key Laboratory of Plateau Lake Ecology and Global Change, Yunnan Normal University. Using a Picarro L2130-i ultra-high precision liquid water and moisture isotope analyzer, the measurement accuracy of $\delta^{18} \mathrm{O}$ and $\delta^{2} \mathrm{H}$ was $\pm 0.1 \%$ o and $\pm 0.5 \%$ o, respectively. The final analysis results were expressed by the thousandth difference relative to the Vienna standard mean ocean water (V-SMOW) as follows:

$$
\begin{aligned}
\delta^{2} \mathrm{H} & =\left(\frac{R_{D-\text { sample }}}{R_{V-S M O W}}-1\right) \times 1000 \% \text { о } \\
\delta^{18} \mathrm{O} & =\left(\frac{R_{O-\text { sample }}}{R_{V-S M O W}}-1\right) \times 1000 \% \text { o }
\end{aligned}
$$

where $R_{\text {sample }}$ and $R_{V \text {-SMOW }}$ represent the oxygen and hydrogen stable isotope ratios of $\mathrm{R}\left({ }^{18} \mathrm{O} /{ }^{16} \mathrm{O}\right)$ and $R(\mathrm{D} / \mathrm{H})$ in the water samples and $V$-SMOW, respectively.

\subsection{Analysis Methods and Data Sources}

The analysis methods included SPSS statistical analysis, correlation testing, ArcGIS geostatistical analysis, and cartographic generalization. The meteorological data was obtained from the small meteorological observation station located in Quanfuzhuang in the middle of the basin, which automatically recorded the hourly data for temperature, humidity, precipitation, and other relevant meteorological elements. The remote sensing images of the study area, showing the terrain and location information of sampling points were downloaded from the Local Space Viewer software at a resolution of $0.6 \mathrm{~m}$. The digital elevation model was provided by the National Geospatial Data Cloud. The hydrogeological data of the basin was derived from the field investigation of the study area and the 1:200,000 regional geological report of the Yuanyang area.

\section{Results and Analysis}

\subsection{Compositional Characteristics of Stable Isotopes Present in Groundwater}

According to the analysis of the test results for stable isotopes present in 120 groundwater samples during the one-year study period, in the middle-altitude terraces of the Quanfuzhuang catchment of the Hani Terraces, the $\delta^{18} \mathrm{O}$ values of groundwater ranged from $-9.65 \%$ o to $-3.01 \%$, with an average value of $-7.29 \%$, and the $\delta^{2} \mathrm{H}$ values ranged from $-65.86 \%$ o to $-37.60 \%$, with an average value of $-51.32 \%$. The $\delta^{18} \mathrm{O}$ and $\delta^{2} \mathrm{H}$ values of groundwater isotopes during the rainy season ranged from $-9.65 \%$ o to $-3.01 \%$ o and from $-65.86 \%$ o to $-37.60 \%$, with average values of $-7.10 \%$ o and $-50.52 \%$, 
respectively. During the dry season, the value ranges were from $-9.55 \%$ o to $-6.01 \%$ o and from $-62.38 \%$ o to $-43.37 \%$, with average values of $-7.47 \%$ o and $52.11 \%$, respectively. Overall, there were minor differences between the dry and rainy season. The average $\delta^{18} \mathrm{O}$ and $\delta^{2} \mathrm{H}$ values during the rainy season were slightly higher than those during the dry season by $0.37 \%$ ond $1.59 \%$, respectively. Both the maximum and minimum values of $\delta^{18} \mathrm{O}$ and $\delta^{2} \mathrm{H}$ occurred during the rainy season. Spatially, the groundwater stable isotope values $\left(\delta^{18} \mathrm{O}\right.$ and $\left.\delta^{2} \mathrm{H}\right)$ along the elevation gradient of $300 \mathrm{~m}$ in the terrace area gradually decreased with increasing elevation. The differences between the stable isotope values at the highest and the lowest sampling points were $-3.04 \%$ and $-15.28 \%$, respectively, and the stable isotope values of spring water changed significantly with elevation.

Based on the measured values of hydrogen and oxygen isotopes present in groundwater from May 2015 to April 2016, the simple linear regression analysis of $\delta^{2} \mathrm{H}$ and $\delta^{18} \mathrm{O}$ in groundwater showed that annually, the relationship between $\delta^{2} \mathrm{H}$ and $\delta^{18} \mathrm{O}$ in the groundwater in the study area is $\delta^{2} \mathrm{H}=$ $4.98 \delta^{18} \mathrm{O}-15.01\left(\mathrm{R}^{2}=0.92, \mathrm{n}=144\right)$. In the rainy season, $\delta^{2} \mathrm{H}=4.89 \delta^{18} \mathrm{O}-15.79\left(\mathrm{R}^{2}=0.90, \mathrm{n}=72\right)$; in the dry season, $\delta^{2} \mathrm{H}=5.19 \delta^{18} \mathrm{O}-13.31\left(\mathrm{R}^{2}=0.95, \mathrm{n}=72\right)$ (Figure 2). The slopes of the $\delta^{2} \mathrm{H}-\delta^{18} \mathrm{O}$ correlation lines of groundwater (LGWL) in the study area were similar for the whole year, the rainy season, and the dry season. The slope of the rainy season was equal to that of the whole year, while the slope of the dry season was slightly larger than that of the rainy season. In addition, the slopes for the whole year, the rainy season, and the dry season in the study area were less than the measured slope (8.31) of the annual local meteoric water line (LMWL) [33] and the slope $(8.14 \pm 0.02)$ of the global meteoric water line (GMWL) [34], which indicates that the main groundwater recharge source is terraced water with strong evaporation.

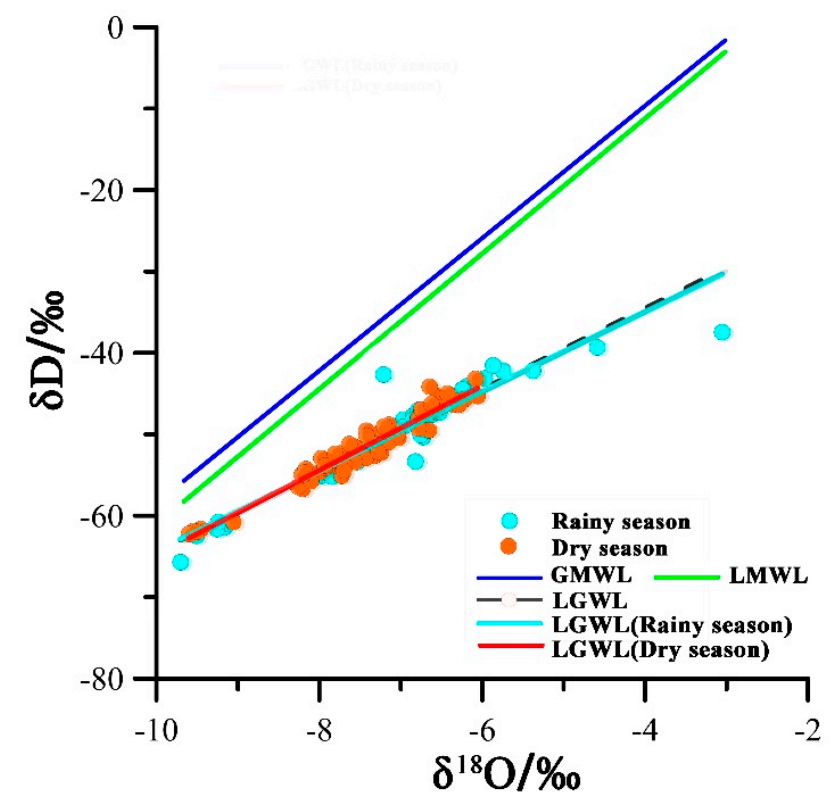

Figure 2. Local groundwater line (LGWL) for the study area across season, based on the data of individual sampling from May 2015 to April 2016.

\subsection{Variation in the Elevation Effect on the Stable Isotope Values of Groundwater}

The groundwater isotope values $\left(\delta^{18} \mathrm{O}\right.$ and $\left.\delta^{2} \mathrm{H}\right)$ of 10 sampling points $\left(\mathrm{D}_{01}-\mathrm{D}_{10}\right)$ in the study area were averaged for each month in one year. It was found that the spatial distribution of the annual spring water isotope values demonstrated an overall decrease with increasing elevation (Figure 3). Through the correlation analysis of the elevation effect on the annual average stable isotope values $\left(\delta^{18} \mathrm{O}\right.$ and $\left.\delta^{2} \mathrm{H}\right)$ of groundwater samples, it was found that the correlation coefficients $\left(\mathrm{r}_{\alpha}\right)$ for the annual groundwater isotope values $\left(\delta^{18} \mathrm{O}\right.$ and $\left.\delta^{2} \mathrm{H}\right)$ and elevation were -0.80 and -0.78 , respectively, at a significance level of 0.05 . The annual stable isotope values $\left(\delta^{18} \mathrm{O}\right.$ and $\left.\delta^{2} \mathrm{H}\right)$ of groundwater have 
significant correlations with the elevation $\left(n=10, r_{a}=0.63\right)$. In other words, there are significant elevation effects. The regression equation can be obtained by regression analysis of the annual average values of $\delta^{18} \mathrm{O}$ and $\delta^{2} \mathrm{H}$ in groundwater and the elevations:

$$
\begin{aligned}
& \delta^{18} \mathrm{O}=-0.0088 \mathrm{~h}+6.91\left(\mathrm{R}^{2}=0.64, \mathrm{n}=10\right) \\
& \delta^{2} \mathrm{H}=-0.0450 \mathrm{~h}+21.27\left(\mathrm{R}^{2}=0.60, \mathrm{n}=10\right)
\end{aligned}
$$

where $\mathrm{h}$ is the elevation, and the unit is $\mathrm{m}$. It was found that the elevation gradients of the annual stable isotope values $\left(\delta^{18} \mathrm{O}\right.$ and $\left.\delta^{2} \mathrm{H}\right)$ of groundwater in the study area were $-0.88 \%$ o $(100 \mathrm{~m})^{-1}$ and $-4.5 \%$ o $(100 \mathrm{~m})^{-1}$, respectively.
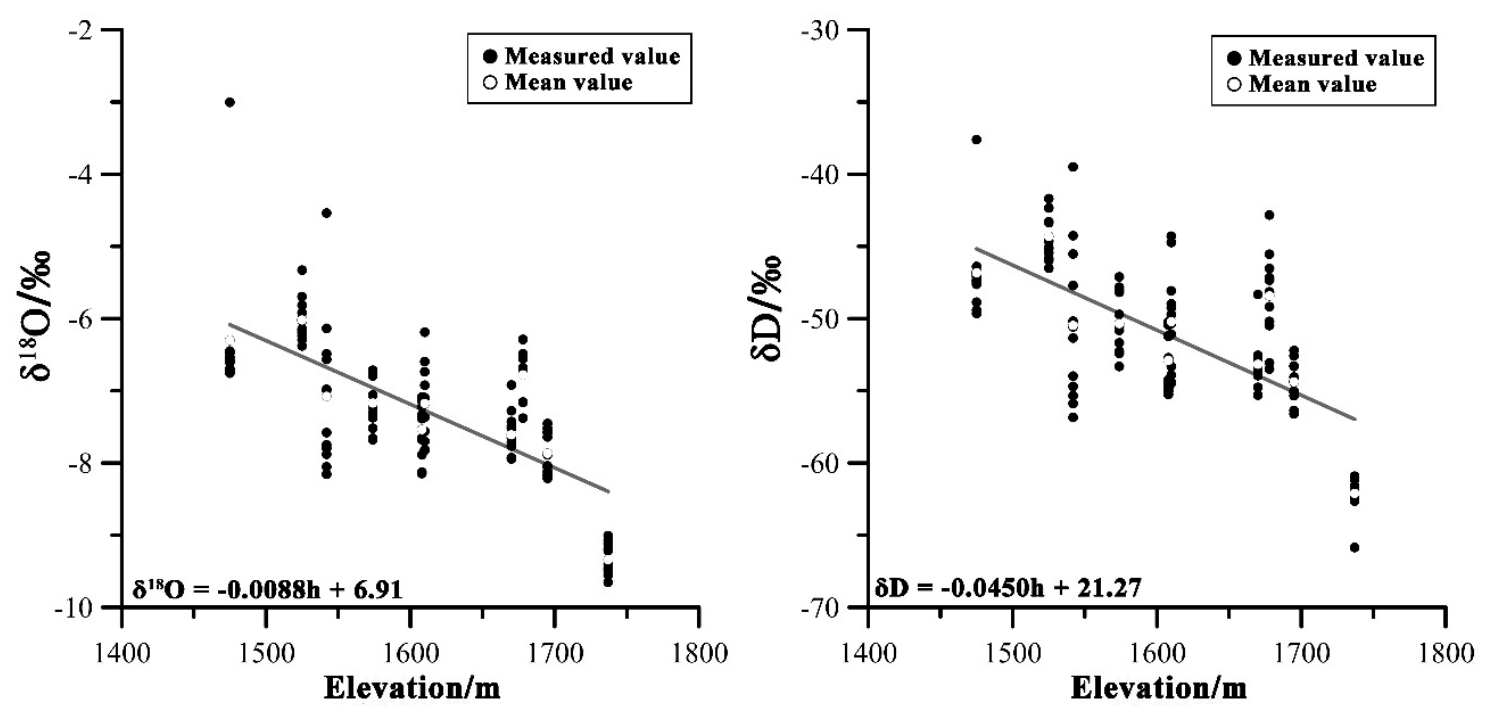

Figure 3. Variation in groundwater isotope values $\left(\delta^{18} \mathrm{O}\right.$ and $\left.\delta^{2} \mathrm{H}\right)$ with elevation.

In order to further explore the temporal change in elevation effect in the study area, we conducted correlation analysis and regression analysis of the groundwater stable isotope values $\left(\delta^{18} \mathrm{O}\right.$ and $\left.\delta^{2} \mathrm{H}\right)$ of 10 sampling points $\left(\mathrm{D}_{01}-\mathrm{D}_{10}\right)$ with elevation. It was found that the groundwater stable isotope values in both the dry and rainy season in the study area had significant correlation with elevation (Table 1). Therefore, the effects of isotopic elevation on the groundwater in the study area were clearly demonstrated. The elevation gradients of the groundwater stable isotope values $\left(\delta^{18} \mathrm{O}\right.$ and $\left.\delta^{2} \mathrm{H}\right)$ in the dry season were $-0.74 \%$ o $(100 \mathrm{~m})^{-1}$ and $-3.76 \%$ o $(100 \mathrm{~m})^{-1}$, respectively, which were lower than those of the spring water stable isotope values $\left(-1.02 \%\right.$ o $(100 \mathrm{~m})^{-1}$ and $-5.25 \%$ o $(100 \mathrm{~m})^{-1}$, respectively) in the rainy season, indicating that there was a higher isotopic elevation gradient in the rainy season. 
Table 1. The relationship between the stable isotope value of groundwater and the elevation in different months in the study area.

\begin{tabular}{ccccc}
\hline \multirow{2}{*}{ Month } & \multicolumn{3}{c}{$\delta^{18} \mathbf{O}$} & $\delta^{2} \mathbf{H}$ \\
\cline { 2 - 5 } & $\begin{array}{c}\text { Correlation } \\
\left.\text { Coefficient( } \mathbf{r}_{\alpha}\right)\end{array}$ & Regression Equation & $\begin{array}{c}\text { Correlation } \\
\text { Coefficient }\left(\mathrm{r}_{\alpha}\right)\end{array}$ & Regression Equation \\
\hline May & $-0.70^{*}$ & $\delta^{18} \mathrm{O}=-0.0073 \mathrm{~h}+4.64$ & $-0.76^{*}$ & $\delta^{2} \mathrm{H}=-0.0452 \mathrm{~h}+21.73$ \\
Jun & $-0.77^{*}$ & $\delta^{18} \mathrm{O}=-0.0084 \mathrm{~h}+6.59$ & $-0.80^{*}$ & $\delta^{2} \mathrm{H}=-0.0491 \mathrm{~h}+29.92$ \\
Jul & $-0.75^{*}$ & $\delta^{18} \mathrm{O}=-0.0109 \mathrm{~h}+10.60$ & $-0.81^{*}$ & $\delta^{2} \mathrm{H}=-0.0583 \mathrm{~h}+44.24$ \\
Aug & $-0.85^{*}$ & $\delta^{18} \mathrm{O}=-0.0170 \mathrm{~h}+20.46$ & $-0.89^{*}$ & $\delta^{2} \mathrm{H}=-0.0741 \mathrm{~h}+69.91$ \\
Sep & $-0.67^{*}$ & $\delta^{18} \mathrm{O}=-0.0077 \mathrm{~h}+5.06$ & $-0.64 *$ & $\delta^{2} \mathrm{H}=-0.0461 \mathrm{~h}+22.29$ \\
Oct & $-0.76^{*}$ & $\delta^{18} \mathrm{O}=-0.0099 \mathrm{~h}+8.51$ & -0.55 & $\delta^{2} \mathrm{H}=-0.0420 \mathrm{~h}+16.05$ \\
Nov & -0.56 & $\delta^{18} \mathrm{O}=-0.0066 \mathrm{~h}+3.14$ & -0.56 & $\delta^{2} \mathrm{H}=-0.0336 \mathrm{~h}+1.48$ \\
Dec & $-0.66^{*}$ & $\delta^{18} \mathrm{O}=-0.0074 \mathrm{~h}+4.36$ & $-0.63 *$ & $\delta^{2} \mathrm{H}=-0.0379 \mathrm{~h}+8.39$ \\
Jan & -0.58 & $\delta^{18} \mathrm{O}=-0.0069 \mathrm{~h}+3.64$ & -0.53 & $\delta^{2} \mathrm{H}=-0.0360 \mathrm{~h}+6.66$ \\
Fed & $-0.70^{*}$ & $\delta^{18} \mathrm{O}=-0.0081 \mathrm{~h}+5.56$ & $-0.71^{*}$ & $\delta^{2} \mathrm{H}=-0.0448 \mathrm{~h}+20.97$ \\
Mar & $-0.76^{*}$ & $\delta^{18} \mathrm{O}=-0.0083 \mathrm{~h}+6.10$ & $-0.666^{*}$ & $\delta^{2} \mathrm{H}=-0.0355 \mathrm{~h}+5.02$ \\
Apr & $-0.83^{*}$ & $\delta^{18} \mathrm{O}=-0.0072 \mathrm{~h}+4.27$ & $-0.83 *$ & $\delta^{2} \mathrm{H}=-0.0380 \mathrm{~h}+8.60$ \\
Rainy season & $-0.87^{*}$ & $\delta^{18} \mathrm{O}=-0.0102 \mathrm{~h}+9.31$ & $-0.84 *$ & $\delta^{2} \mathrm{H}=-0.0525 \mathrm{~h}+34.02$ \\
Dry season & $-0.70^{*}$ & $\delta^{18} \mathrm{O}=-0.0074 \mathrm{~h}+4.51$ & $-0.67 *$ & $\delta^{2} \mathrm{H}=-0.0376 \mathrm{~h}+8.52$ \\
Annual & $-0.80^{*}$ & $\delta^{18} \mathrm{O}=-0.0088 \mathrm{~h}+6.91$ & $-0.78^{*}$ & $\delta^{2} \mathrm{H}=-0.0450 \mathrm{~h}+21.27$ \\
\hline
\end{tabular}

Note: the sample number is 10 . When $\left|\mathrm{r}_{\alpha}\right| \geq 0.63$, the correlation coefficient passes the correlation test, and this is denoted as "**".

During the dry-rainy season cycle (12 months) in the study area, most months demonstrated significant elevation effects, except for November and January which showed no elevation effect was shown (Table 2). The months with elevation effects accounted for $83.3 \%$ of the dry-rainy season cycle (12 months). Further analysis showed that November and January, when there was no elevation effect, and December, when the elevation effect was not significant, were in the transition period from the rainy season (May to October) to the dry season (November to April of the following year). The change in precipitation during this period may be one of the factors that affects groundwater elevation effects in the study area. The impact of farming activities in this area is also an important factor. Therefore, the change in elevation effect on groundwater during the transition period between rainy and dry seasons is discussed further. 
Table 2. $\delta^{18} \mathrm{O}$ and $\delta^{2} \mathrm{H}$ of groundwater at sampling points along the elevation transect.

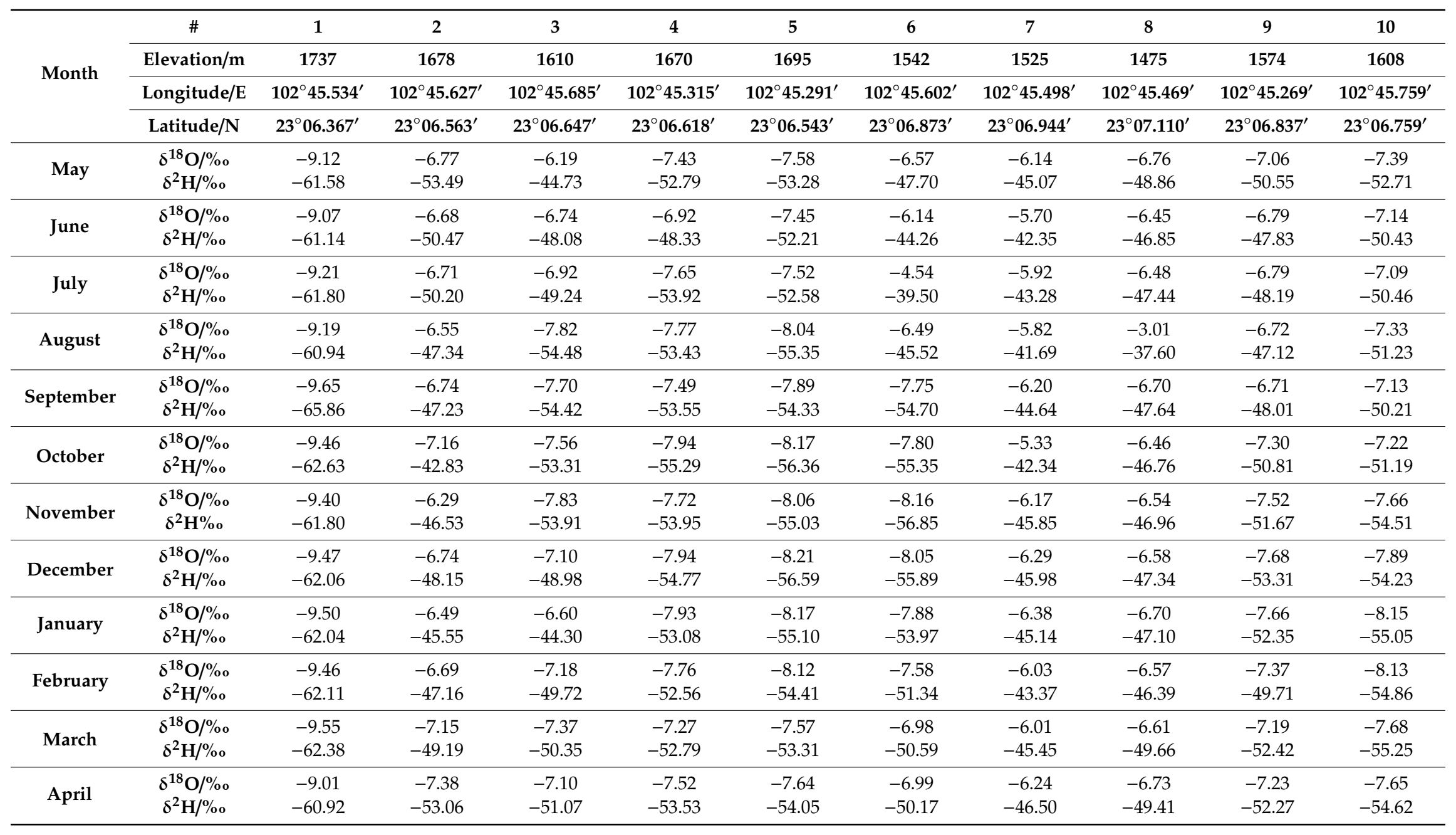




\section{Discussion}

5.1. Spatial Effect: The Influence of Terraced Farming on the Elevation Effect on Hydrogen and Oxygen Isotopes Present in Groundwater

It is generally believed that the aquifer in the study area was dug through due to large-scale terrace excavation in the area. Consequently, a large amount of groundwater was discharged to the surface in the terrace area, resulting in the mixing of groundwater and surface water and reducing the elevation effect on groundwater in the study area. However, the current research indicates that groundwater in the terrace area still has a significant elevation effect, which is clearly related to the fact that the terraces in the study area are rice terraces.

Firstly, groundwater in the terrace area will be recharged by the terraced water and lateral infiltration caused by the height differences between the terraces. However, the overall influence is weak. This is the reason why the overall elevation effect on groundwater in the study area was relatively significant (Figure 4). Research on the Hani Terraces by Jiao (2009) also showed that the Hani Terraces are irrigated throughout the year with the exception of the harvest season (around October). The water depth is generally between $20 \mathrm{~cm}$ and $25 \mathrm{~cm}$ and the terrace water storage is $0.25 \mathrm{~m}^{3} / \mathrm{m}^{2}$ [35]. The bottom mud of the terraces is generally clay with low permeability, and farmers conduct real-time maintenance. Man-made rice terraces have better water-holding capacity, therefore, the loss of field water caused by leakage in terraces is almost negligible [35]. Rice cultivation over a long time and regular repair to prevent terrace leakage make surface water (field water) infiltration in the terraces quite difficult; this is the key reason that terrace groundwater maintains a better elevation gradient effect.
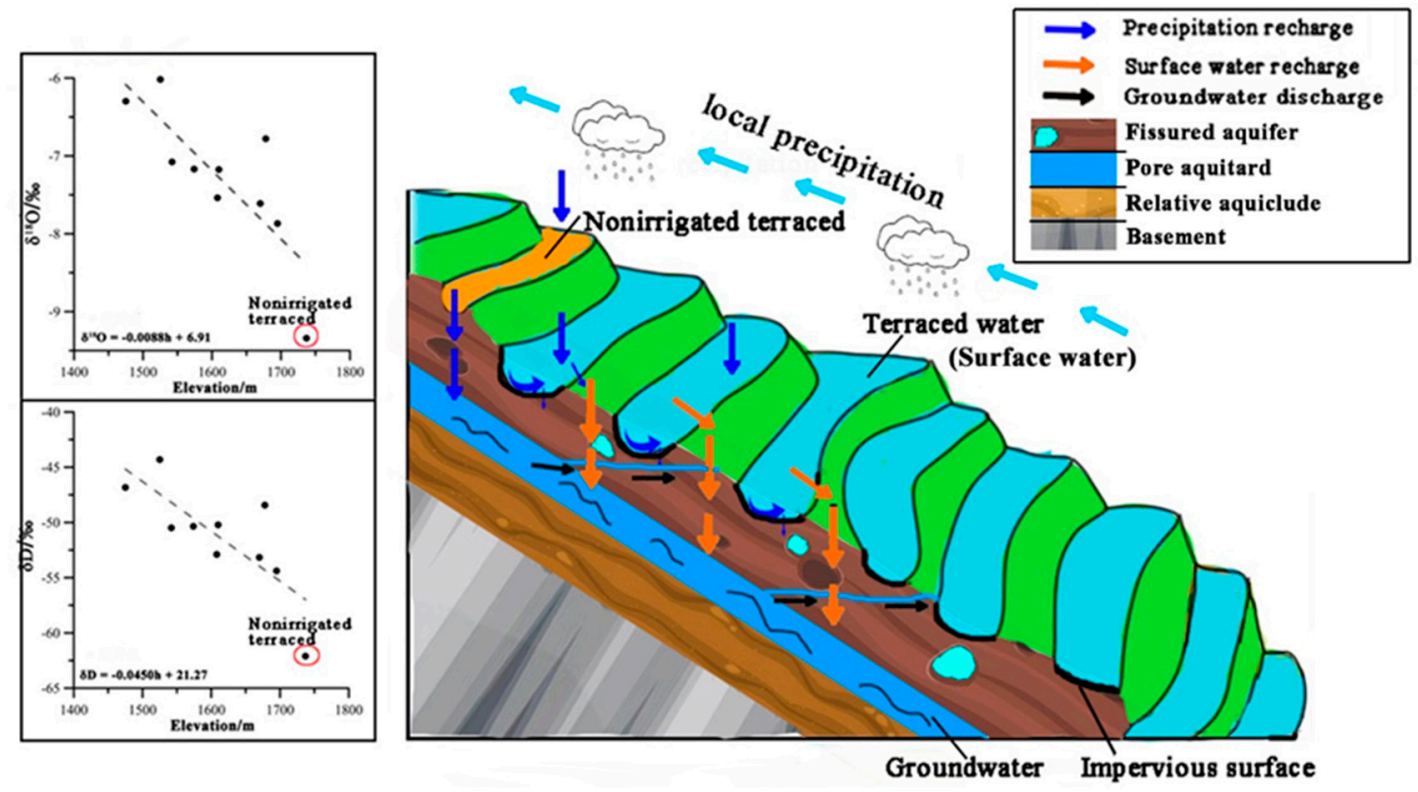

Figure 4. Spatial effect on groundwater under the influence of farming activities (schematic diagram).

However, the elevation gradients of the annual stable isotope values $\left(\delta^{18} \mathrm{O}\right.$ and $\left.\delta^{2} \mathrm{H}\right)$ of groundwater in the terrace area are $-0.88 \%$ o $(100 \mathrm{~m})^{-1}$ and $-4.5 \%$ o $(100 \mathrm{~m})^{-1}$, respectively. These values are more than twice the elevation effect gradients of the stable isotope values $\left(\delta^{18} \mathrm{O}\right.$ and $\left.\delta^{2} \mathrm{H}\right)$ of groundwater in Slovenia: $-0.33 \%$ o $(100 \mathrm{~m})^{-1}(\mathrm{r}=-0.89, p<0.01)$ and $-2.40 \%$ o $(100 \mathrm{~m})^{-1}(\mathrm{r}=-0.89, p<0.01)$, respectively [36]. Compared with the elevation gradient of $\delta^{18} \mathrm{O}$ of the global precipitation, which is between $-0.5 \%$ o $(100 \mathrm{~m})^{-1}$ and $-0.15 \%$ o $(100 \mathrm{~m})^{-1}$ with an average value of $-0.28 \%$ o $(100 \mathrm{~m})^{-1}$ [37], the elevation gradients of groundwater isotopes in the study area completely exceed this range. However, the elevation gradient of $\delta^{18} \mathrm{O}$ of groundwater in the mountainous Hasi area in northwest China is $-0.118 \%$ o $(100 \mathrm{~m})^{-1}$, which is less than this range [38]. This is due to the influence of farming 
activities on the surface water infiltration rate. As shown in Figure 4, the infiltration rate of rice terraces is different to that of dry fields. The surface water in rice terraces is controlled by the impermeable layer at the bottom of the terraces, which means water cannot infiltrate rapidly into the soil. Due to evaporation on the surface over a long period of time, the water isotope value tends to be more positive. In dry fields, precipitation and surface water can infiltrate rapidly into soil, so the isotope value tends to be more negative. When water in two different regions is recharged to the groundwater, if the elevation of the dry field is higher, the spatial difference in isotope values will be intensified and the elevation gradient of the groundwater stable isotope values will be larger. If the elevation of the dry field is lower, the spatial difference will be weakened, and the elevation gradient will be smaller or even tend to be positive. Therefore, the groundwater elevation effect gradient can be used as an indicator to determine the source of groundwater recharge, which is closely related to the landform change caused by local farming activities, and there are large differences between different regions.

\subsection{Temporal Effect: The Relationship between the Terrace Farming Cycle and the Groundwater Recharge Cycle}

The deuterium excess (also called d-excess, or $d$ value) was first proposed and defined as $d=\delta^{2} \mathrm{H}$ $-8 \delta^{18} \mathrm{O}$ by Dansgaared [39]. It reflects the degree of deviation of the composition of the hydrogen and oxygen isotope from the global meteoric water line, and to a certain extent, the differences between different water vapor sources. In detailed studies of the $d$ value, many researchers have also applied the $d$ value to other water bodies for analysis. In order to clarify the temporal variations in the elevation effect on groundwater stable isotopes in the study area, the $d$ value of the groundwater was analyzed. As shown in Figure 5, the variation in the deuterium excess value of groundwater in the study area in each month was between $5.72 \%$ ond $8.99 \%$, with an average value of $6.98 \%$, and the $d$ value had significantly different characteristics in terms of time. In particular, the $d$ value from May to August was relatively low, ranging from $5.4 \%$ o to $6 \%$. From September to February, the $d$ value increased continuously and was between 7\%o and 9\%o; and from March to April it dropped below 7\%o. From September to February in the study area, the change in $d$ value of spring water was relatively stable, and this coincided with a period of precipitation during the rainy season, which to some extent indicates that the groundwater in this period was likely recharged by the infiltration of water bodies by precipitation and surface water. This was three months after the rainy season in the study area. Therefore, it takes approximately three months for precipitation to infiltrate into the groundwater layer in the study area.

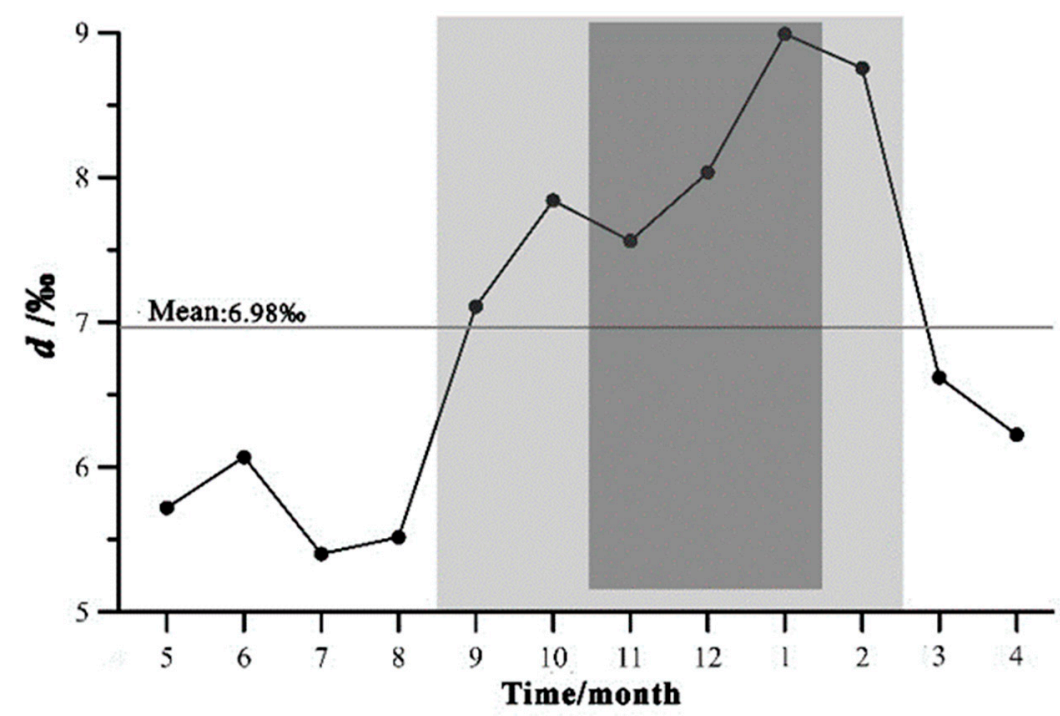

Figure 5. Variation in the deuterium excess of groundwater with time in the study area. 
In the winter after rice harvesting, the Hani people need to plough the terraces to repair them. This is the reason why the elevation effect on groundwater in the study area was not significant in some months. The results of field investigation and research by local cultural researchers shows that local residents in the study area are engaged in large-scale agricultural activities related to terrace farming between November and January. This mainly involves the deep ploughing of terraces and re-irrigation (Figure 6). During this period, the impervious layer originally formed in the terraces is destroyed by human activity. Consequently, a large amount of field water or other surface water, for example, ditch water is recharged to the groundwater layer, which strengthens the supply of surface water to groundwater and thus weakens the elevation effect on groundwater in this period. The rapid increase in the $d$ value of groundwater in the study area from December to January also indicates that there is a significant change in the supply water source during this period.

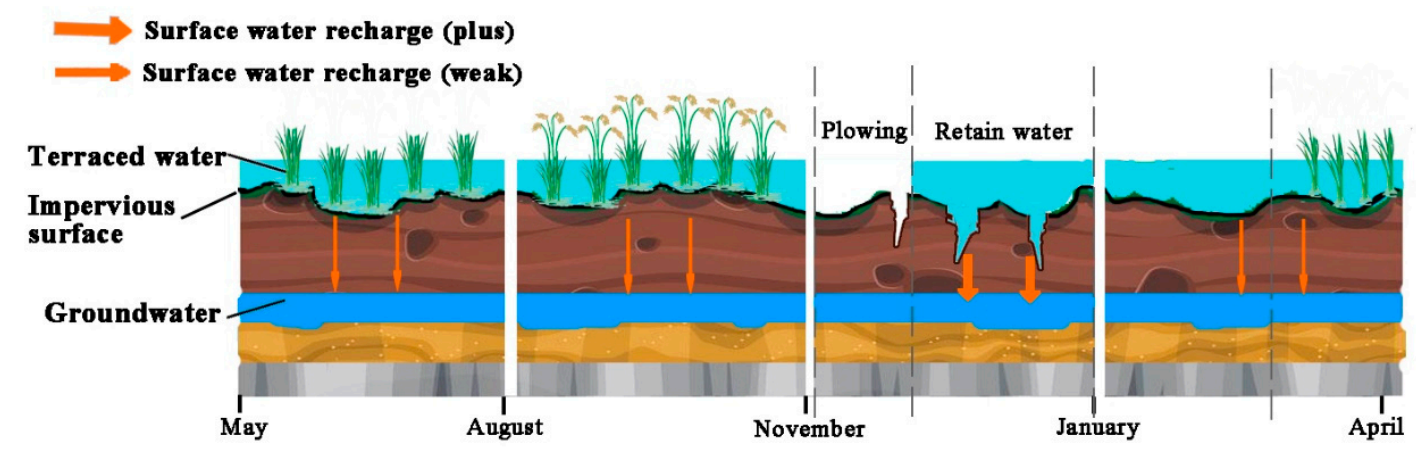

Figure 6. Spatial effect on groundwater under the influence of farming activities.

The ploughing activities are necessary for the maintenance of the terraces. Such activities also accelerate the infiltration of terraced water, thus increasing the supply of terraced water to groundwater. This provides sufficient water for groundwater recharge in the dry season and lays a solid foundation for farming in the early dry season of the following year. This is one of the key factors for sustainable cultivation in the Hani Terraces.

\section{Conclusions}

Through the testing and analysis of groundwater stable isotope samples at different elevations, this study has revealed the characteristic variations and influencing factors of temporal and spatial effects on the stable isotopes of groundwater in the Hani Terraces, which are under the influence of high-intensity farming activities. It was found that moderate farming activities can increase infiltration into groundwater. We also used the special temporal and spatial variation characteristics of groundwater isotopes as a means to predict the source and periodic changes in groundwater recharge.

In terms of spatial effects, the degree of mixing between groundwater and surface water in rice terraces maintained by farming activities is small, unlike dryland terraces. Stable isotopes of groundwater in the terraces have significant elevation effects. The elevation gradients of $\delta^{18} \mathrm{O}$ and $\delta^{2} \mathrm{H}$ were $-0.88 \%$ o $(100 \mathrm{~m})^{-1}$ and $-4.5 \%$ o $(100 \mathrm{~m})^{-1}$, respectively. The values in the terrace area exceeded the elevation gradients of atmospheric precipitation. This indicates that the multi-source groundwater recharge and farming activities in the study area create uncertainty about the location of surface water infiltration, which increases or decreases the elevation gradient of regional groundwater. The elevation gradient of groundwater can be used as a key index for assessing groundwater recharge.

In terms of temporal effects, rice cultivation is the key factor influencing the change in elevation effect on groundwater in the terrace area. The high-intensity rice cultivation that takes place from October to January accelerates the infiltration of surface water and strengthens the interaction between groundwater and surface water, resulting in no obvious elevation effect in this period. According to the temporal variation in the deuterium excess value of groundwater in the study area, it was inferred that 
the groundwater circulation time in the terrace area is approximately three months, and the sudden increase in the $d$ value from October to January is also related to high-intensity rice cultivation.

In addition, high-intensity rice cultivation during the period from October to January increases the supply of terraced water to groundwater. This provides sufficient water for groundwater recharge before the dry season and thus ensures the sustainability of rice cultivation activities in the terraces during the dry season. This is one of the key reasons why the Hani Terraces have lasted for more than 1300 years, and also reflects how human wisdom can play a role in the sustainable and benign transformation of surface cover and the regulation of groundwater circulation.

Author Contributions: Conceptualization, Y.J.; Funding acquisition, Y.J.; Writing—original draft, C.L.; 一review \& editing, Y.J.; Formal analysis, D.Z. and Q.X.; Software, Y.D.; Investigation, Z.L.; Resources, Y.J. and Q.X. All authors have read and agreed to the published version of the manuscript.

Funding: This research was funded by the National Natural Science Foundation of China grant number 41271203 and 41761115. The APC was funded by School of Tourism and Geographical Sciences, Yunnan Normal University.

Acknowledgments: The authors thank Hucai Zhang of Yunnan University for the lab experiment with the water samples, Mingjun Zhang and Master's student Xiuxiu Yu of Northwest Normal University, and two anonymous reviewers and the editorial staff for constructive feedback that resulted in an improved manuscript.

Conflicts of Interest: The authors declare no conflicts of interest. The funders had no role in the design of the study; in the collection, analyses, or interpretation of data; in the writing of the manuscript; or in the decision to publish the results.

\section{References}

1. Aeschbachhertig, W.; Gleeson, T. Regional strategies for the accelerating global problem of groundwater depletion. Nat. Geosci. 2012, 5, 853-861. [CrossRef]

2. Michael, I.; Rizzo, L.; McArdell, C.S.; Manaia, C.M.; Merlin, C.; Schwartz, T.; Dagot, C.; Fatta-Kassinos, D. Urban wastewater treatment plants as hotspots for the release of antibiotics in the environment: A review. Water Res. 2013, 47, 957-995. [CrossRef] [PubMed]

3. Gleeson, T.; Befus, K.M.; Jasechko, S.; Luijendijk, E.; Cardenas, M.B. The global volume and distribution of modern groundwater. Nat. Geosci. 2016, 9, 161-164. [CrossRef]

4. Cartwright, I.; Cendon, D.I.; Currell, M.; Meredith, K.T. A review of radioactive isotopes and other residence time tracers in understanding groundwater recharge: Possibilities, challenges, and limitations. J. Hydrol. 2017, 555, 797-811. [CrossRef]

5. Lei, Y.; Hoskins, B.J.; Slingo, J.M. Exploring the interplay between natural decadal variability and anthropogenic climate change in summer rainfall over China. Part I: Observational evidence. J. Clim. 2011, 24, 4584-4599. [CrossRef]

6. Meixner, T.; Manning, A.H.; Stonestrom, D.A.; Allen, D.M.; Ajami, H.; Blasch, K.W.; Brookfield, A.E.; Castro, C.L.; Clark, J.F.; Gochis, D.J.; et al. Implications of projected climate change for groundwater recharge in the western United States. J. Hydrol. 2016, 534, 124-138. [CrossRef]

7. Rimi, R.H.; Haustein, K.; Allen, M.R.; Barbour, E. Risks of pre-monsoon extreme rainfall events of Bangladesh: Is anthropogenic climate change playing a role? Bull. Am. Meteorol. Soc. 2019, 100, S61-S65. [CrossRef]

8. Roderick, T.P.; Wasko, C.; Sharma, A. Atmospheric moisture measurements explain increases in tropical rainfall extremes. Geophys. Res. Lett. 2019, 46, 1375-1382. [CrossRef]

9. Negrel, P.; Ollivier, P.; Flehoc, C.; Hube, D. An innovative application of stable isotopes $\left(\delta^{2} \mathrm{H}\right.$ and $\left.\delta^{18} \mathrm{O}\right)$ for tracing pollutant plumes in groundwater. Sci. Total Environ. 2017, 578, 495-501. [CrossRef]

10. Dansgaared, W. The abundance of $\mathrm{O}^{18}$ in atmospheric water and water vapor. Tellus 1953, 5, 461-469.

11. Gat, J.R. Oxygen and hydrogen isotopes in the hydrologic cycle. Annu. Rev. Earth Planet. Sci. 1996, 24, 225-262. [CrossRef]

12. Juras, R.; Pavlasek, J.; Vitvar, T.; Sanda, M.; Holub, J.; Jankovec, J.; Linda, M. Isotopic tracing of the outflow during artificial rain-on-snow event. J. Hydrol. 2016, 541, 1145-1154. [CrossRef]

13. Orlowski, N.; Kraft, P.; Pferdmenges, J.; Breuer, L. Exploring water cycle dynamics by sampling multiple stable water isotope pools in a developed landscape in Germany. Hydrol. Earth Syst. Sci. 2016, 20, 3873-3894. [CrossRef] 
14. Mook, W.; Gat, J.; Meijer, H.; Rozanski, K.; Froehlich, K. Environmental Isotopes in the Hydrological Cycle: Principles and Applications-Vol. I, Introduction: Theory, Methods, Review; IHP-V Technical Documents in Hydrology, N³9; UNESCO-IAEA: Vienna, Austria, 2001; pp. 61-70.

15. Jodar, J.; Custodio, E.; Liotta, M.; Lamban, L.J.; Herrera, C.; Martosrosillo, S.; Sapriza, G.; Rigo, T. Correlation of the seasonal isotopic amplitude of precipitation with annual evaporation and altitude in alpine regions. Sci. Total Environ. 2016, 550, 27-37. [CrossRef] [PubMed]

16. Cerar, S.; Mezga, K.; Žibret, G.; Urbanc, J.; Komac, M. Comparison of prediction methods for oxygen-18 isotope composition in shallow groundwater. Sci. Total Environ. 2018, 631-632, 358-368. [CrossRef] [PubMed]

17. Bortolami, G.C.; Ricci, B.; Susella, G.F.; Zuppi, G.M. Isotope Hydrology of the Val Vorsaglia, Maritime Alps, Piedmont, Italy; IAEA Proceedings Series v1; International Atomic Energy Agency: Vienna, Austria, 1979; pp. 327-378.

18. Darling, W.G.; Bath, A.H. A stable isotope study of recharge processes in the English Chalk. J. Hydrol. 1988, 101, 31-46. [CrossRef]

19. Yonge, C.J.; Goldenberg, L.; Krouse, H.R. An isotope study of water bodies along a traverse of southwestern Canada. J. Hydrol. 1989, 106, 245-255. [CrossRef]

20. Gieske, A.; Selaolo, E.; Mcmullan, S. Groundwater recharge through the unsaturated zone of southeastern Botswana: A study of chlorides and environmental isotopes. IAHS-AISH Publ. 1990, 191, 33-44.

21. Edirisinghe, E.A.N.V.; Karunarathne, G.R.R.; Samarakoon, A.S.M.N.B.; Pitawala, H.M.T.G.A.; Tilakarathna, I.A.N.D.P. Assessing causes of quality deterioration of groundwater in puttalam, Sri Lanka, using isotope and hydrochemical tools. Isot. Environ. Health Stud. 2016, 52, 1-16. [CrossRef]

22. Huang, T.; Pang, Z.; Li, J.; Xiang, Y.; Zhao, Z. Mapping groundwater renewability using age data in the Baiyang alluvial fan, NW China. Hydrogeol. J. 2017, 25, 743-755. [CrossRef]

23. Joshi, S.K.; Rai, S.P.; Sinha, R.; Gupta, S.; Shekhar, S. Tracing groundwater recharge sources in the northwestern Indian alluvial aquifer using water isotopes $\left(\delta^{18} 0, \delta^{2} \mathrm{H}\right.$ and $\left.{ }^{3} \mathrm{H}\right)$. J. Hydrol. 2018, 559, 835-847. [CrossRef]

24. Scanlon, B.R.; Reedy, R.C.; Stonestrom, D.A.; Prudic, D.E.; Dennehy, K.F. Impact of land use and land cover change on groundwater recharge and quality in the southwestern US. Glob. Chang. Biol. 2005, 11, 1577-1593. [CrossRef]

25. Vrba, J.; Hirata, R.; Girman, J.; Haie, N.; Lipponen, A.; Neupane, B.; Shah, T.; Wallin, B. Groundwater resources sustainability indicators. In The Global Importance of Groundwater in the 21st Century: Proceedings of the International Symposium on Groundwater Sustainability, Alicante, Spain, 24-27 January 2006; Ragone, S., Ed.; National Groundwater Association: Westerville, OH, USA, 2007; pp. 129-138.

26. Huang, T.; Pang, Z. Estimating groundwater recharge following land-use change using chloride mass balance of soil profiles: A case study at Guyuan and Xifeng in the loess plateau of China. Hydrogeol. J. 2011, 19, 177-186. [CrossRef]

27. Vorosmarty, C.J.; Lettenmaier, D.P.; Leveque, C.; Meybeck, M.; Pahlwostl, C.; Alcamo, J.; Cosgrove, W.J.; Grassl, H.; Hoff, H.; Kabat, P.; et al. Humans transforming the global water system. Eos Trans. Am. Geophys. Union 2004, 85, 509-514. [CrossRef]

28. Mays, L.W. Groundwater resources sustainability: Past, present, and future. Water Resour. Manag. 2013, 27, 4409-4424. [CrossRef]

29. Allison, G.B.; Cook, P.G.; Barnett, S.; Walker, G.R.; Jolly, I.; Hughes, M.W. Land clearance and river salinisation in the western Murray basin, Australia. J. Hydrol. 1990, 119, 1-20. [CrossRef]

30. Liu, C.J.; Jiao, Y.M.; Zhang, G.L.; Liu, X.; Zhang, T.Y. Altitude effect of hydrogen and oxygen isotopes in spring water of the Malizhai river basin in Hani terrace. J. Glaciol. Geocryol. 2016, 38, 1404-1410.

31. Jiao, Y.M.; Liu, C.J.; Liu, X.; Liu, Z.L.; Ding, Y.P. Impacts of dominated landscape types on hydrogen and oxygen isotope effects of spring water in the Hani rice terraces. Chin. J. Appl. Ecol. 2017, 28, 2299-2306.

32. Yunnan Geological Survey Bureau. 1:200,000 Regional Geological Report of the Yuanyang Areas; Yunnan Geological Survey Bureau: Kunming, China, 1971; pp. 20-31.

33. Jiao, Y.; Liu, C.; Gao, X.; Xu, Q.; Ding, Y.; Liu, Z. Impacts of moisture sources on the isotopic inverse altitude effect and amount of precipitation in the Hani rice terraces region of the Ailao mountains. Sci. Total Environ. 2019, 687, 470-478. [CrossRef]

34. Gourcy, L.L.; Groening, M.; Aggarwal, P.K. Stable oxygen and hydrogen isotopes in precipitation. In Isotopes in the Water Cycle: Past, Present and Future of Developing Science; Aggarwal, P.K., Gat, J.R., Froehlich, K.F.O., Eds.; Springer: Dordrecht, The Netherlands, 2005; pp. 39-51. 
35. Jiao, Y.M. Natural and Cultural Landscape Ecology of Hani Terraces Beijing; China Environmental Science Press: Beijing, China, 2009; pp. 1-12.

36. Mezga, K.; Urbanc, J.; Cerar, S. The isotope altitude effect reflected in groundwater: A case study from Slovenia. Isot. Environ. Health Stud. 2014, 50, 33-51. [CrossRef]

37. Chamberlain, C.P.; Poage, M.A. Reconstructing the paleotopography of mountain belts from the isotopic composition of authigenic minerals. Geology 2000, 28, 115-118. [CrossRef]

38. Xing, X.H.; Liu, G.M.; Li, H.Q.; Hu, G.L. Sources of spring water and its characteristics of hydrogen and oxygen stable isotopes in Hasi Mountain. J. China Hydrol. 2016, 36, 46-50.

39. Dansgaared, W. Stable isotopes in precipitation. Tellus 1964, 16, 463-468.

(C) 2020 by the authors. Licensee MDPI, Basel, Switzerland. This article is an open access article distributed under the terms and conditions of the Creative Commons Attribution (CC BY) license (http://creativecommons.org/licenses/by/4.0/). 